\title{
Screening for cytotoxic chemical constituents from Justicia procumbens by HPLC- DAD-ESI-MS and NMR
}

\author{
Bo Liu', Yanfang Yang ${ }^{1,2,3}$, Hongbin Liu' ${ }^{4}$, Zhoutao Xie ${ }^{1}$, Qun Li ${ }^{1}$, Meng Deng ${ }^{1}$, Fangping Li', Jingling Peng ${ }^{1}$ \\ and Hezhen $\mathrm{Wu}^{1,2,3^{*}}$
}

\begin{abstract}
Background: The Acanthaceae family is an important source of therapeutic drugs and ethno medicines. There are many famous medicinal plants from this family, such as Andrographis paniculata, Baphicacanthus cusia, and Dicliptera chinensis. Justicia procumbens (J. procumbens) is widely distributed in tropical and sub-tropical of the world. It has long been used in traditional Chinese medicine for cancer. The 3-(4,5-dimethylthiazol-2-yl)-2,5-diphenyltetrazolium bromide assay showed the ethyl acetate extract of J. procumbens had a cytotoxic activity. Therefore, qualitative and quantitative analysis of the chemical constituents in the ethyl acetate extract was important for understanding its pharmacological mechanism.
\end{abstract}

Results: A high-performance liquid chromatography with diode array detection coupled to electrospray ionisation quadrupole time-of-flight tandem mass spectrometry procedure was established. Eleven dibenzylbutanes and four arylnaphthalenes were confirmed by HPLC-DAD-ESI-QTOF-MS analysis. A novel dibenzylbutane (5-methoxy-4,4'-diO-methylsecolariciresinol-9'-monoacetate) and seven isomers of arylnaphthalene were isolated and characterized by NMR and QTOF-MS. Compounds 1, 2, and 13 were detected for the first time. The content of six lignans were determinated in the ethyl acetate extract.

Conclusions: This study showed that the cytotoxic activity assay of J. procumbens could be mainly attributed to the constituents of lignans. The bioactivity of the ethyl acetate extract and determined compounds support the traditional use of this plant in cancer. These chemical constituents may be developed as novel therapeutics.

Keywords: Lignan, Justicia procumbens, HPLC-DAD-MS, Chemical constituents, Structural analysis, Determinate content

\section{Background}

The Acanthaceae family is used in many South and East Asia countries as the ethno pharmacological medicines. Some researchers have indicated that Acanthaceae possess antifungal, cytotoxic, anti-inflammatory, anti-pyretic, hepatoprotective, immunomodulatory, antiplatelet aggregation and anti-viral potential [1]. This family has about 35 genera and 304 species in China. Justicia is the largest genus. J. procumbens is a commonly used

\footnotetext{
*Correspondence: hezh_wu@163.com

${ }^{1}$ Faculty of Pharmacy, Hubei University of Chinese Medicine, No.1,

Huangjiahu West Road, Wuhan 430065, China

Full list of author information is available at the end of the article
}

traditional herbal medicine embodied in Chinese Pharmacopoeia 1977 version. The entire plant has long been used to treat laryngeal inflammation, pain, and cancer in China [2]. There are abundant resources in south China.

In the preliminary study, the EtOH extract of J. procumbens was suspended in water and partitioned with petroleum ether, ethyl acetate, and $n-\mathrm{BuOH}$. The results of the MTT assay showed that the ethyl acetate extract had a stronger cytotoxic activity against the human lung epithelial cell A549 than the other extract (Fig. 1). Therefore, it was important to identify the chemical constituents in the ethyl acetate extract. 


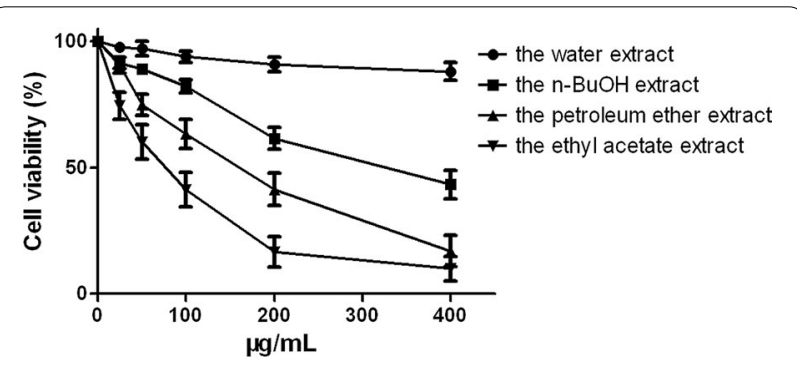

Fig. 1 The inhibition effect of four extracts on A549 cells. Each value represents the mean \pm SD of five separate experiments

In the past years, diverse compounds have been isolated from $J$. procumbens, mainly arylnaphthalide and diarylbutane lignans, and their glycosides [3, 4]. However, these individual chemical studies were characterized by long span of time, accidentally discover, and subsection. HPLCMS combining the selected chromatographic column with quantitative analysis could provide the whole landscape of characteristic chromatogram from plants $[5,6]$. By matching with this characteristic chromatogram, a complete and systematic phytochemistry study could be carried out without missing any of potential active compounds.

In order to reveal effective substances in the ethyl acetate extract of $J$. procumbens, a HPLC-ESI-QTOF-MS analysis method has been developed. To improve liquid chromatographic resolution, an ether-linked phenyl column was used. The structure of the unidentified isomeride and novel compound were characterized by NMR. Finally, 23 lignans were identified. Compound 12 is novel. Compounds 1,2 , and 13 were detected for the first time. The simultaneous analysis of the lignans present in J. procumbens using HPLC-DAD-ESI-MS has not been reported.

\section{Experimental methods}

\section{Materials and chemicals}

The plant materials of J. procumbens were collected from Wuchang district, Hubei province of China in 2014. They were authenticated by Prof. Keli Chen, Hubei University of Chinese Medicine. All the voucher specimens (JC-2014-ZYYDX) were deposited in the pharmaceutical college.

The human lung epithelial cell A549 were obtained from China Center for Type Culture Collection (Wuhan, China). Roswell Park Memorial Institute (RPMI) 1640 medium, fetal bovine serum (FBS), and penicillin-streptomycin were purchased from Gibco Corporation (New York, USA). MTT (thiazolyl blue tetrazolium bromide) and dimethyl sulfoxide (DMSO) were purchased from Sigma-Aldrich Corporation (St. Louis, MO, USA).

HPLC-MS grade acetonitrile was purchased from Fisher Scientific UK (Loughborough, UK). All other analytical grade reagents were purchased from Shanghai Chemical Reagent Corporation of China Medicine Group (Shanghai, China). The water for HPLC analysis was prepared using a Milli-Q SP Regent Water system (Millipore, USA).

\section{Extraction and isolation}

The entire plants were dried at room temperature for 1 week and then ground to fine powder using a mechanical grinder. The powdered sample $(30 \mathrm{~kg})$ was immersed in $75 \% \mathrm{EtOH}(240 \mathrm{~L})$. After the evaporation of $\mathrm{EtOH}$ under reduced pressure at $50{ }^{\circ} \mathrm{C}$, the residues $(8.8 \mathrm{~L})$ were successively partitioned using petroleum ether (590 g), ethyl acetate $(240 \mathrm{~g})$, and $n-\mathrm{BuOH}(360 \mathrm{~g})$. The ethyl acetate extract (200 g) was chromatographed on silica gel using a mixture of $\mathrm{CHCl}_{3}-\mathrm{MeOH}$ (50:1 to $\left.1: 1\right)$ and on Sephadex LH-20 using a mixture of $\mathrm{CHCl}_{3}-$ $\mathrm{MeOH}$ and $\mathrm{MeOH}$. Eight compounds, 5-methoxy-4,4'di-O-methylsecolariciresinol-9'-monoacetate $(16 \mathrm{mg})$, justicidinoside B (117 mg), justicidinoside C (182 mg), procumbenoside B (105 $\mathrm{mg})$, procumbenoside $\mathrm{H}$ (79 mg), justicidin B (636 mg), chinensinaphthol methyl ether (217 mg), and neojusticin B (93 mg) were obtained. The structures of these compounds were elucidated from their MS and NMR spectral data.

\section{Assays for cytotoxic activity Cell culture}

The human lung epithelial cells A549 grown adhesively in RPMI 1640 medium supplemented with 10\% fetal bovine serum (FBS), $100 \mathrm{U} / \mathrm{ml}$ penicillin and $100 \mathrm{U} / \mathrm{ml}$ streptomycin. Cells were cultured at $37{ }^{\circ} \mathrm{C}$ in $5 \% \mathrm{CO}_{2}$ humidified atmosphere. The cell passage was carried out every 2-3 days.

\section{MTT assay}

Cells were seeded in 96-well plated at a density of $1 \times 10^{4}$ cells $/ \mathrm{ml}$ in a volume of $100 \mu \mathrm{l} /$ well. After cells adhesion was observed, the spent medium was removed and replaced with $100 \mu \mathrm{l}$ of fresh medium doped with different concentrations of the four extracts $(25,50$, 100,200 , and $400 \mu \mathrm{g} / \mathrm{ml}$ ) for $48 \mathrm{~h}$ in quintuplicate. Subsequently, $20 \mu \mathrm{l}$ of $5 \mathrm{mg} / \mathrm{ml}$ MTT solution were added followed by incubation for an additional $4 \mathrm{~h}$. Then, the supernatant was discarded and $100 \mu \mathrm{l}$ of DMSO was added each well. The absorbance was measured at $570 \mathrm{~nm}$ with plate reader use (Biotek, Cytation 3). The results were expressed as percentage viability.

\section{Standard and sample preparation}

The standard stock solutions of justicidinoside B $(0.42 \mathrm{mg} / \mathrm{ml})$, justicidinoside $\mathrm{C}(0.59 \mathrm{mg} / \mathrm{ml})$, procumbenoside $\mathrm{H}(0.37 \mathrm{mg} / \mathrm{ml})$, justicidin $B(0.92 \mathrm{mg} / \mathrm{ml})$, 
chinensinaphthol methyl ether $(0.34 \mathrm{mg} / \mathrm{ml})$, and neojusticin $B(0.44 \mathrm{mg} / \mathrm{ml})$ were prepared in methanol and stored at $4{ }^{\circ} \mathrm{C}$. Appropriate concentrations were diluted for preparing calibration curves and the mixed standard solution. The solutions were filtered through a $0.45 \mu \mathrm{m}$ membrane prior to injection.

The ethyl acetate extract powder $(40 \mathrm{mg}$ ) was accurately weighed and placed in a $250 \mathrm{ml}$ capped conical flask. Then, $100 \mathrm{ml}$ methanol was added, and the mixture was extracted using an ultrasonic bath $(50 \mathrm{~Hz})$ for $30 \mathrm{~min}$. The extract was filtered through a $0.45 \mu \mathrm{m}$ membrane filter. Finally, $10 \mu \mathrm{l}$ of the sample was injected into an HPLC instrument for analysis.

\section{HPLC-DAD-ESI-QTOF-MS conditions}

The HPLC analysis was performed using an Agilent 1260 Infinity system (Agilent, America). Chromatographic separations of the analytes were carried out using a Synergi Polar-RP 80 A column $(4.6 \mathrm{~mm} \times 250 \mathrm{~mm}, 4 \mu \mathrm{m}$ particle size) obtained from Phenomenex at $30{ }^{\circ} \mathrm{C}$. The mobile phase consisted of water (solvent $\mathrm{A}$ ) and acetonitrile (solvent $\mathrm{B}$ ); the gradient program was as follows: 0 min $15 \%$ B, 130 min 35\% B, and 175 min $45 \%$ B. The flow rate was $1.0 \mathrm{ml} / \mathrm{min}$, and the injection volume was $10 \mu \mathrm{l}$. The on-line UV spectra were recorded in the range 190-400 nm.

The QTOF-MS spectra were acquired using a micrOTOF-Q mass spectrometer equipped with an ESI source (Bruker Daltonics, Bremen, Germany). The optimized MS operating conditions were as follows: capillary voltage $4500 \mathrm{~V}$, nebulizer gas pressure $0.8 \mathrm{bar}$, drying gas flow rate $8 \mathrm{l} / \mathrm{min}$, dry gas heater temperature $200{ }^{\circ} \mathrm{C}$ in the positive ion mode $\left(\mathrm{ESI}^{+}\right)$. The mass scan range was set at $m / z 50-1600$.

\section{NMR conditions}

The ${ }^{1} \mathrm{H}$-NMR spectra of justicidinoside $\mathrm{B}$, justicidinoside $C$, procumbenoside $B$, procumbenoside $H$, justicidin $B$, chinensinaphthol methyl ether, and neojusticin $B$ were recorded using Bruker Avance III $600 \mathrm{MHz}$ instrument. These arylnaphthalenes were dissolved in $\mathrm{CD}_{3} \mathrm{OD}$.

The ${ }^{1} \mathrm{H}-\mathrm{NMR},{ }^{13} \mathrm{C}-\mathrm{NMR},{ }^{1} \mathrm{H}-{ }^{1} \mathrm{H}$ COSY, HSQC, and $\mathrm{HMBC}$ spectra of 5-methoxy-4,4'-di-Omethylsecolariciresinol-9'-monoacetate were recorded using Bruker Avance III $800 \mathrm{MHz}$ instrument. This dibenzylbutane was dissolved in $\mathrm{CDCl}_{3}$.

\section{Results and discussion}

\section{Evaluation of cytotoxic effect}

A549 cells were cultured in a medium containing different concentrations of the four extracts for $48 \mathrm{~h}$. The cell viabilities were determined by MTT assay as shown in Fig. 1. We found that cell growth was inhibited in the following order: the ethyl acetate extract $>$ the petroleum ether extract $>$ the $n-\mathrm{BuOH}$ extract $>$ the water extract. The ethyl acetate extract had a stronger cytotoxic activity than the other extracts and dose-effect relationship was observed. The $\mathrm{IC}_{50}$ of this extract was $66.93 \mu \mathrm{g} / \mathrm{ml}$.

\section{Screening high performance liquid chromatography}

A good chromatographic separation of the constituents in the ethyl acetate extract of J. procumbens was achieved using a reverse-phase column and a gradient elution with a mixture of water and acetonitrile. The hydrophilic and hydrophobic lignans were determined simultaneously using an ether-linked phenyl column (Synergi Polar-RP $80 \mathrm{~A})$. These compounds showed a low resolution on a C18 column. The ratio of acetonitrile in the mobile phase was increased to $100 \%$ after the gradient program, none peak was observed. This result indicated that all of compounds in the ethyl acetate extract have been detected in $175 \mathrm{~min}$. The ionization mode was very influential on the number of detected chemical substances in the ethyl acetate extract of $J$. procumbens. The positive ionization mode was the most favorable to identify chemical substances as it clearly provided a higher sensitivity.

More than 23 peaks were detected in the MS total ion current (TIC) chromatogram in the positive ion mode (Fig. 2). The exact molecular weight and MS fragmentation data of the 23 compounds are summarized in Table 1 . Their structures were deduced by carefully studying the HRMS, and NMR spectral data and by comparing with the library of compounds obtained from the plant of Justicia genus. The 23 compounds included 11 dibenzylbutanes and 12 arylnaphthalenes (Fig. 3).

The compound 5-methoxy-4,4'-di-O-methylsecolariciresinol-9'-monoacetate (12) was identified for the first time. This is the first report that two glycosides ( $\mathbf{1}$ and $\mathbf{2})$ of secoisolariciresinol dimethyl ether and 5-methoxy4,4'-di-O-methylsecolariciresinol, one monoacetate (13) of secoisolariciresinol dimethyl ether were detected. Further structural studies of the three compounds are underway.

\section{Identification of dibenzylbutanes}

Dibenzylbutane lignans are molecules with two benzene rings in their structure that can be divided into two subgroups. The first fragmentation stage is the cleavage of the glycosidic or acetic bound to yield the $\mathrm{m} / \mathrm{z}$ of the dibenzylbutane lignan and the neutral mass loss of sugar or acetoxy molecules. The second characteristic fragmentation stage is the bond cleavage between $\mathrm{C} 8$ and $\mathrm{C}^{\prime}$. The fragmentations of this stage are helpful to identify the specific dibenzylbutane lignans directly.

Compounds 18, 13, 7, and 2 showed similar characteristic features in the mass spectra. All of them showed 


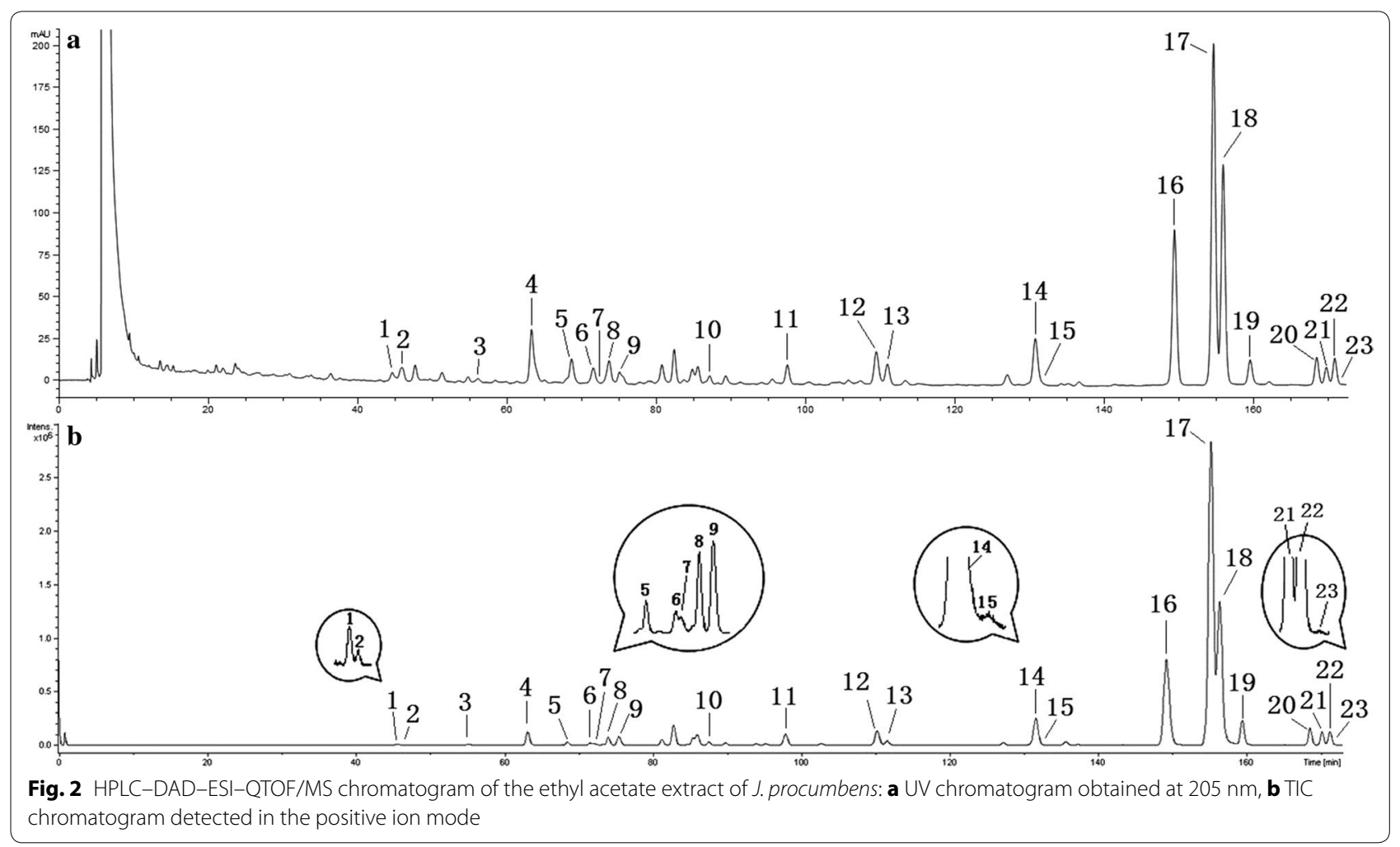

fragment ions nearby $m / z$ 355.1899, 165.0902, and 151.0753 (Table 1). Compound 18 showed a $[\mathrm{M}+\mathrm{Na}]^{+}$ ion at $m / z$ 497.2147, and its chemical formula is $\mathrm{C}_{26} \mathrm{H}_{34} \mathrm{O}_{8}$. The MS spectrum showed two main fragments at $\mathrm{m} / z 355.1899$ (loss of diacetate) and $\mathrm{m} / z 151.0753$ $\left(\mathrm{C}_{9} \mathrm{H}_{11} \mathrm{O}_{2}{ }^{+}\right)$. The characteristic fragment ion at $\mathrm{m} / \mathrm{z}$ 217.0839 was attributed to the bond cleavage between $\mathrm{C} 8$ and $\mathrm{C}^{\prime}$. The fragment pathways are shown in Fig. 4 . This compound was identified as secoisolariciresinol dimethyl ether diacetate by matching with the library [3].

Compound 13 showed a $[\mathrm{M}+\mathrm{Na}]^{+}$ion at $m / z 455.2024$, and its chemical formula is $\mathrm{C}_{24} \mathrm{H}_{32} \mathrm{O}_{7}$. Two ions at $m / z$ 395.1824 $[\mathrm{M}+\mathrm{Na}-\mathrm{HOAc}]^{+}$, and $373.1992[\mathrm{M}+\mathrm{H}-$ $\mathrm{HOAc}^{+}$were observed. This compound was tentatively identified as secoisolariciresinol dimethyl ether monoacetate.

Compound 7 showed a $[\mathrm{M}+\mathrm{Na}]^{+}$ion at $m / z$ 413.1920, and its chemical formula is $\mathrm{C}_{22} \mathrm{H}_{30} \mathrm{O}_{6}$. Two peaks were observed at $m / z 373.1999\left[\mathrm{M}+\mathrm{H}-\mathrm{H}_{2} \mathrm{O}\right]^{+}$and 355.1888 $\left[\mathrm{M}+\mathrm{H}-2 \mathrm{H}_{2} \mathrm{O}\right]^{+}$. The structure was deduced as secoisolariciresinol dimethyl ether [7].

Compound 2 showed a $[\mathrm{M}+\mathrm{Na}]^{+}$ion at $m / z 575.2471$ $\left(\mathrm{C}_{28} \mathrm{H}_{40} \mathrm{NaO}_{11}{ }^{+}\right)$and the aglycone fragment ion at $\mathrm{m} / z$ 391.2113, $[\mathrm{M}+\mathrm{H}-162]^{+}$, indicating a loss of hexose from the parent ion. The characteristic ions shown in Table 1 confirm that the aglycone was compound 7 . However, the glycosilation position and the structure of hexose could not be obtained by MS.

Compounds 17, 12, 6, and 1 showed similar characteristic features in the mass spectra. The mass spectrum of compound 17 showed a molecular ion peak at $m / z 527.2250[\mathrm{M}+\mathrm{Na}]^{+}$, and its chemical formula is $\mathrm{C}_{27} \mathrm{H}_{36} \mathrm{O}_{9}$. The most abundant fragment peak at $\mathrm{m} / \mathrm{z}$ 385.1997 was produced by the loss of diacetate from $[\mathrm{M}+\mathrm{H}]^{+}$ion. The formation of a characteristic fragment ion at $m / z 247.0944$ with chemical formula $\mathrm{C}_{12} \mathrm{H}_{16} \mathrm{NaO}_{4}{ }^{+}$ and another ion at $m / z 217.0824$ with chemical formula $\mathrm{C}_{11} \mathrm{H}_{14} \mathrm{NaO}_{3}{ }^{+}$can be attributed to the bond cleavage between $\mathrm{C} 8$ and $\mathrm{C} 8$ '. Other characteristic fragment ions were observed at $m / z 445.2235,403.2104,195.1007$, 181.0853, 177.0912, and 151.0752 (Fig. 4 and Table 1). Some similar patterns of mass spectra were observed for compounds 1, 6, and 12. They showed similar fragment pathways. The structure of this compound was confirmed as 5-methoxy-4,4'-di-O-methylsecolariciresinol diacetate by comparing with the Ref. [3].

Compound 12 produced a $[\mathrm{M}+\mathrm{Na}]^{+}$ion at $\mathrm{m} / \mathrm{z}$ 485.2140, and its chemical formula is $\mathrm{C}_{25} \mathrm{H}_{34} \mathrm{O}_{8}$. The main peak was observed at $m / z 403.2097[\mathrm{M}+\mathrm{H}-\mathrm{HOAc}]^{+}$. It is the same as 5-methoxy-4,4'-di-O-methylsecolariciresinol monoacetate. But the position of acetoxy wasn't confirmed by MS. 
Table 1 Characterization of 23 compounds in the ethyl acetate extract of J. Procumbens by HPLC-DAD-ESI-MS

\begin{tabular}{|c|c|c|c|c|c|c|c|}
\hline & $\mathrm{RT}$ (min) & $\lambda_{\max }(\mathrm{nm})$ & Formula & Parent ion & $\begin{array}{l}\text { Exact molecular } \\
\text { weight }\end{array}$ & Fragmentation & Identification \\
\hline 1 & 45.5 & - & $\mathrm{C}_{29} \mathrm{H}_{42} \mathrm{O}_{12}$ & {$[\mathrm{M}+\mathrm{Na}]^{+}$} & 605.2578 & $\begin{array}{l}\text { 421.2211, } 403.2114,385.2000,181.0855 \\
\quad 151.0759\end{array}$ & Glycoside of compound 6 \\
\hline 2 & 45.8 & - & $\mathrm{C}_{28} \mathrm{H}_{40} \mathrm{O}_{11}$ & {$[\mathrm{M}+\mathrm{Na}]^{+}$} & 575.2471 & $391.2113,355.1881,165.0916,151.0760$ & Glycoside of compound 7 \\
\hline 3 & 57.9 & 262 & $\mathrm{C}_{26} \mathrm{H}_{26} \mathrm{O}_{11}$ & {$[\mathrm{M}+\mathrm{Na}]^{+}$} & 537.1351 & $353.1012,335.0906,307.0968$ & Procumbenoside $\mathrm{L}$ \\
\hline 4 & 63.1 & 257 & $\mathrm{C}_{27} \mathrm{H}_{26} \mathrm{O}_{12}$ & {$[\mathrm{M}+\mathrm{Na}]^{+}$} & 565.1319 & $381.0953,337.1061323 .0912,307.0951$ & Justicidinoside C \\
\hline 5 & 67.8 & 265 & $\mathrm{C}_{27} \mathrm{H}_{28} \mathrm{O}_{12}$ & {$[\mathrm{M}+\mathrm{Na}]^{+}$} & 567.1475 & $\begin{array}{l}383.1113,369.1001,365.0987,339.1217 \\
\quad 337.1064\end{array}$ & Procumbenoside $\mathrm{K}$ \\
\hline 6 & 71.5 & - & $\mathrm{C}_{23} \mathrm{H}_{32} \mathrm{O}_{7}$ & {$[\mathrm{M}+\mathrm{Na}]^{+}$} & 443.2026 & $\begin{array}{l}403.2015,385.2002,247.0938,217.0828 \\
\quad 181.0851,151.0760\end{array}$ & $\begin{array}{l}\text { 5-methoxy-4,4'-di-O- } \\
\text { methylsecolariciresinol }\end{array}$ \\
\hline 7 & 73.3 & - & $\mathrm{C}_{22} \mathrm{H}_{30} \mathrm{O}_{6}$ & {$[\mathrm{M}+\mathrm{Na}]^{+}$} & 413.1920 & $\begin{array}{l}373.1999,355.1888,217.0831,165.0911 \\
151.0754\end{array}$ & $\begin{array}{l}\text { Secoisolariciresinol dimethyl } \\
\text { ether }\end{array}$ \\
\hline 8 & 74.0 & 263 & $\mathrm{C}_{28} \mathrm{H}_{28} \mathrm{O}_{13}$ & {$[\mathrm{M}+\mathrm{Na}]^{+}$} & 595.1420 & $411.1063,367.1164,337.1056$ & Justicidinoside B \\
\hline 9 & 75.4 & 264 & $\mathrm{C}_{32} \mathrm{H}_{34} \mathrm{O}_{16}$ & {$[\mathrm{M}+\mathrm{H}]^{+}$} & 675.1892 & $513.1393,381.0951$ & Procumbenoside B \\
\hline 10 & 87.5 & 265 & $\mathrm{C}_{31} \mathrm{H}_{32} \mathrm{O}_{15}$ & {$[\mathrm{M}+\mathrm{H}]^{+}$} & 645.1806 & $513.1393,381.0952$ & Procumbenoside $\mathrm{H}$ \\
\hline 11 & 97.8 & 263 & $\mathrm{C}_{26} \mathrm{H}_{24} \mathrm{O}_{11}$ & {$[\mathrm{M}+\mathrm{H}]^{+}$} & 513.1395 & 381.0951 & Tuberculatin \\
\hline 12 & 110.1 & 279 & $\mathrm{C}_{25} \mathrm{H}_{34} \mathrm{O}_{8}$ & {$[\mathrm{M}+\mathrm{Na}]^{+}$} & 485.2140 & $403.2097,385.1991,181.0853,151.0757$ & $\begin{array}{l}\text { 5-methoxy-4,4'-di-O- } \\
\text { methylsecolariciresinol-9'- } \\
\text { monoacetate }\end{array}$ \\
\hline 13 & 111.5 & 282 & $\mathrm{C}_{24} \mathrm{H}_{32} \mathrm{O}_{7}$ & {$[\mathrm{M}+\mathrm{Na}]^{+}$} & 455.2024 & $\begin{array}{l}395.1824,373.1992,355.1904,165.0904 \\
151.0758\end{array}$ & $\begin{array}{l}\text { Secoisolariciresinol dimethyl } \\
\text { ether monoacetate }\end{array}$ \\
\hline 14 & 131.4 & 264 & $\mathrm{C}_{26} \mathrm{H}_{34} \mathrm{O}_{9}$ & {$[\mathrm{M}+\mathrm{Na}]^{+}$} & 513.2113 & $\begin{array}{l}371.1845,339.1584,233.0795,217.0843 \\
177.0910,167.0702,151.0758\end{array}$ & Justin C \\
\hline 15 & 131.5 & - & $\mathrm{C}_{28} \mathrm{H}_{26} \mathrm{O}_{12}$ & {$[\mathrm{M}+\mathrm{H}]^{+}$} & 555.1495 & $513.1407,381.0947$ & Diphyllin apioside-5-acetate \\
\hline 16 & 149.0 & 258 & $\mathrm{C}_{21} \mathrm{H}_{16} \mathrm{O}_{6}$ & {$[\mathrm{M}+\mathrm{Na}]^{+}$} & 387.0824 & $335.0899,321.0749$ & Justicidin B \\
\hline 17 & 155.0 & $201,228,278$ & $\mathrm{C}_{27} \mathrm{H}_{36} \mathrm{O}_{9}$ & {$[\mathrm{M}+\mathrm{Na}]^{+}$} & 527.2250 & $\begin{array}{l}\text { 505.2422, 445.2235, 403.2104, 385.1997, } \\
\text { 247.0944, 217.0824, 195.1007, } \\
\text { 181.0853, 177.0912, 151.0752 }\end{array}$ & $\begin{array}{l}\text { 5-methoxy-4,4'-di-O- } \\
\text { methylsecolariciresinol } \\
\text { diacetate }\end{array}$ \\
\hline 18 & 156.2 & $201,230,280$ & $\mathrm{C}_{26} \mathrm{H}_{34} \mathrm{O}_{8}$ & {$[\mathrm{M}+\mathrm{Na}]^{+}$} & 497.2147 & $\begin{array}{l}355.1899,325.1806,313.1792,269.1535 \\
217.0839,195.1005,165.0902 \\
151.0753\end{array}$ & $\begin{array}{l}\text { Secoisolariciresinol dimethyl } \\
\text { ether diacetate }\end{array}$ \\
\hline 19 & 159.2 & 262 & $\mathrm{C}_{22} \mathrm{H}_{18} \mathrm{O}_{7}$ & {$[\mathrm{M}+\mathrm{H}]^{+}$} & 395.1108 & $365.1015,351.0859,319.0972$ & Chinensinaphthol methyl ether \\
\hline 20 & 168.3 & 262 & $\mathrm{C}_{22} \mathrm{H}_{18} \mathrm{O}_{7}$ & {$[\mathrm{M}+\mathrm{H}]^{+}$} & 395.1110 & 365.1007 & Neojusticin B \\
\hline 21 & 169.9 & 282 & $\mathrm{C}_{26} \mathrm{H}_{32} \mathrm{O}_{9}$ & {$[\mathrm{M}+\mathrm{Na}]^{+}$} & 511.1916 & $\begin{array}{l}387.1791,369.1693,247.0931,201.0521 \\
195.1009,181.0851,151.0759\end{array}$ & (-)-dihydroclusin diacetate \\
\hline 22 & 171.0 & 284 & $\mathrm{C}_{25} \mathrm{H}_{30} \mathrm{O}_{8}$ & {$[\mathrm{M}+\mathrm{Na}]^{+}$} & 481.1809 & $\begin{array}{l}339.1580,201.0527,177.0904,165.0910 \\
151.0753,135.0449\end{array}$ & $\begin{array}{l}\text { 2,3-demethoxysecisolintetralin } \\
\text { acetate }\end{array}$ \\
\hline 23 & 171.7 & - & $\mathrm{C}_{20} \mathrm{H}_{12} \mathrm{O}_{6}$ & {$[\mathrm{M}+\mathrm{H}]^{+}$} & 349.0648 & 305.0795 & Justicidin E \\
\hline
\end{tabular}

Compound 6 showed a $[\mathrm{M}+\mathrm{Na}]^{+}$ion at $m / z 443.2026$, and its chemical formula is $\mathrm{C}_{23} \mathrm{H}_{32} \mathrm{O}_{7}$. The characteristic fragment ions were observed at $\mathrm{m} / z$ 403.2105 [M+H$\left.\mathrm{H}_{2} \mathrm{O}\right]^{+}$and $385.2002\left[\mathrm{M}+\mathrm{H}-2 \mathrm{H}_{2} \mathrm{O}\right]^{+}$. The structure was deduced as 5-methoxy-4,4'-di-O-methylsecolariciresinol [8].

Compound 1 showed a $[\mathrm{M}+\mathrm{Na}]^{+}$ion at $m / z 605.2578$ $\left(\mathrm{C}_{29} \mathrm{H}_{42} \mathrm{NaO}_{12}{ }^{+}\right)$and the aglycone fragment ion at $\mathrm{m} / \mathrm{z}$ 421.2211, $[\mathrm{M}+\mathrm{H}-162]^{+}$, indicating a loss of hexose from the mother ion. The characteristic fragments of aglycone were in accordance with compound 6 (Table 1). However, it was not possible to establish the exact glycosilation position (at $\mathrm{C} 9$ or $\mathrm{C} 9^{\prime}$ ) and the structure of hexose.
Compound 14 showed a $[\mathrm{M}+\mathrm{Na}]^{+}$ion at $m / z 513.2113$, and its chemical formula is $\mathrm{C}_{26} \mathrm{H}_{34} \mathrm{O}_{9}$. The main peaks were observed at 233.0795, and 167.0702 (Fig. 5). The fragmentations showed peaks at $\mathrm{m} / z 371.1845[\mathrm{M}+\mathrm{H}-$ $2 \mathrm{HOAc}$ ], 339.1584 [M+H-2HOAc- $\mathrm{CH}_{2}-\mathrm{H}_{2} \mathrm{O}$ ], 217.0843, 177.0910, and 151.0758. This compound was confirmed as Justin C [3].

Compound 21 showed a $[\mathrm{M}+\mathrm{Na}]^{+}$ion at $m / z 511.1916$, and its chemical formula is $\mathrm{C}_{26} \mathrm{H}_{32} \mathrm{O}_{9}$. The characteristic fragment ions at $m / z 387.1791[\mathrm{M}+\mathrm{H}-\mathrm{HOAc}-\mathrm{Ac}]^{+}$and $369.1693[\mathrm{M}+\mathrm{H}-2 \mathrm{HOAc}]^{+}$indicated the loss of diacetate from the parent ion. The main ion was observed at $\mathrm{m} / \mathrm{z}$ $201.0521\left(\mathrm{C}_{10} \mathrm{H}_{10} \mathrm{NaO}_{3}{ }^{+}\right)$(Fig. 5). The other characteristic 

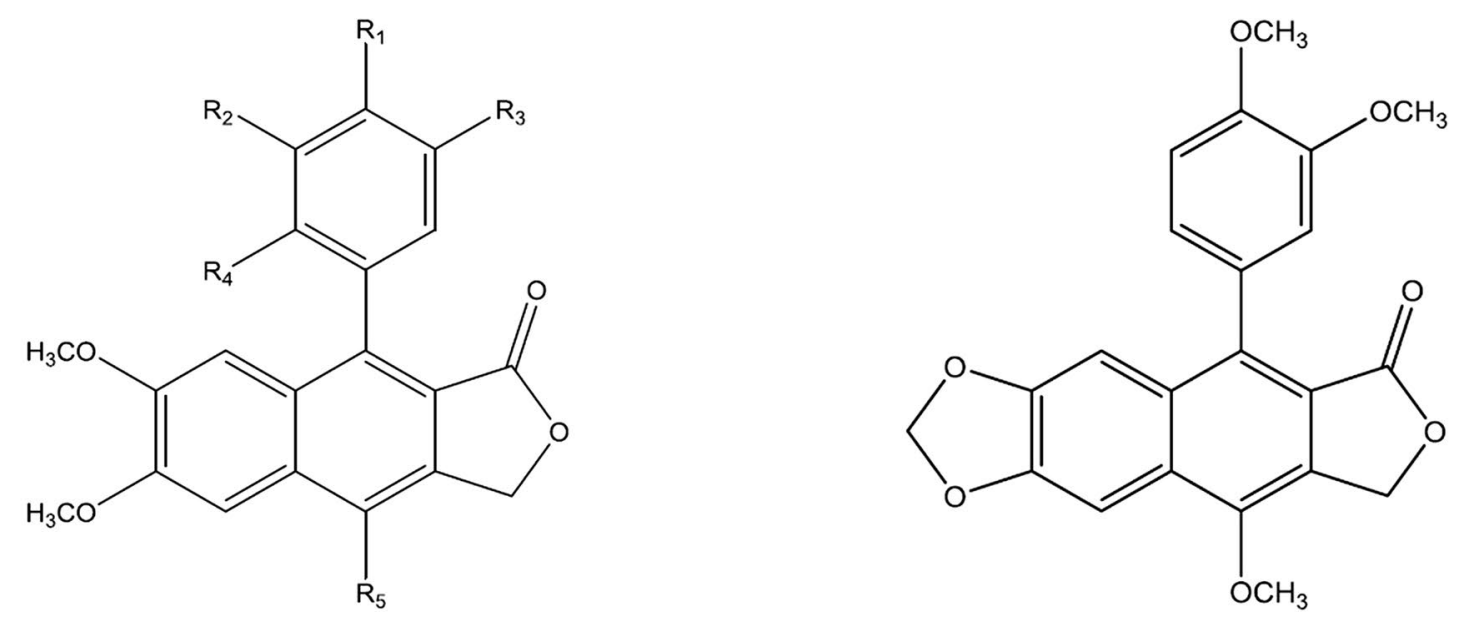

$3 \quad \mathrm{R}_{1}=\beta$-D-glucopyranosyloxy, $\quad \mathrm{R}_{2}=\mathrm{OH}, \quad \mathrm{R}_{3}=\mathrm{H}, \quad \mathrm{R}_{4}=\mathrm{R}_{5}=\mathrm{H}$

19

$4 \quad \mathrm{R}_{1}-\mathrm{R}_{3}=-\mathrm{OCH}_{2} \mathrm{O}-, \quad \mathrm{R}_{2}=\mathrm{H}, \quad \mathrm{R}_{4}=\beta$-D-glucopyranosyloxy, $\quad \mathrm{R}_{5}=\mathrm{H}$

$5 \quad \mathrm{R}_{1}=\beta$-D-glucopyranosyloxy, $\quad \mathrm{R}_{2}=\mathrm{OH}, \quad \mathrm{R}_{3}=\mathrm{H}, \quad \mathrm{R}_{4}=\mathrm{H}, \quad \mathrm{R}_{5}=\mathrm{OMe}$

$8 \quad \mathrm{R}_{1}-\mathrm{R}_{3}=-\mathrm{OCH}_{2} \mathrm{O}-, \quad \mathrm{R}_{2}=\mathrm{H}, \quad \mathrm{R}_{4}=\beta$-D-glucopyranosyloxy, $\quad \mathrm{R}_{5}=\mathrm{OMe}$

$9 \quad \mathrm{R}_{1}-\mathrm{R}_{3}=-\mathrm{OCH}_{2} \mathrm{O}-, \quad \mathrm{R}_{2}=\mathrm{R}_{4}=\mathrm{H}, \quad \mathrm{R}_{5}=\beta$-D-glucopyranosyl- $\left(1^{\prime \prime \prime} \rightarrow 2^{\prime \prime}\right)-O-\beta$-D-apiofuranosyloxy

$10 \mathrm{R}_{1}-\mathrm{R}_{3}=-\mathrm{OCH}_{2} \mathrm{O}-, \quad \mathrm{R}_{2}=\mathrm{R}_{4}=\mathrm{H}, \quad \mathrm{R}_{5}=\beta$-D-xylosepyranosyl-(1"' $\left.\rightarrow 5^{\prime \prime}\right)-O-\beta$ - D-apiofuranosyloxy

$11 \mathrm{R}_{1}-\mathrm{R}_{3}=-\mathrm{OCH}_{2} \mathrm{O}-, \quad \mathrm{R}_{2}=\mathrm{R}_{4}=\mathrm{H}, \quad \mathrm{R}_{5}=\beta$-D-apiofuranosyloxy

$15 \mathrm{R}_{1}-\mathrm{R}_{3}=-\mathrm{OCH}_{2} \mathrm{O}-, \quad \mathrm{R}_{2}=\mathrm{R}_{4}=\mathrm{H}, \quad \mathrm{R}_{5}=$ apioside-5-acetate

$16 \mathrm{R}_{1}-\mathrm{R}_{3}=-\mathrm{OCH}_{2} \mathrm{O}-, \quad \mathrm{R}_{2}=\mathrm{R}_{4}=\mathrm{R}_{5}=\mathrm{H}$

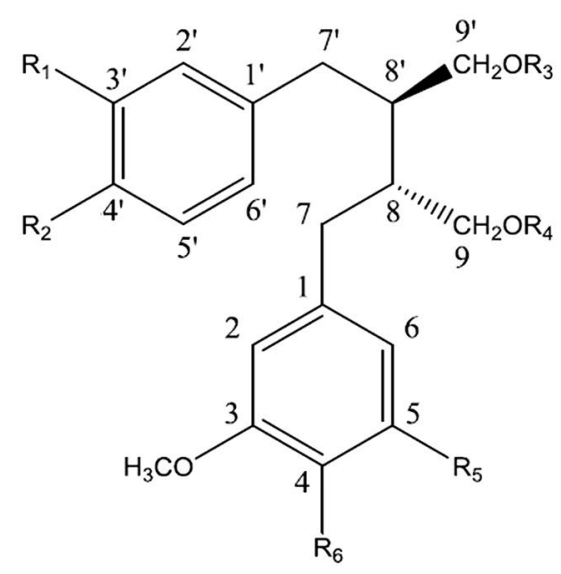

7

$12 \mathrm{R}_{1}=\mathrm{R}_{2}=\mathrm{OMe}, \quad \mathrm{R}_{3}=\mathrm{Ac}, \quad \mathrm{R}_{4}=\mathrm{H}, \quad \mathrm{R}_{5}=\mathrm{R}_{6}=\mathrm{OMe}$

$13 \mathrm{R}_{1}=\mathrm{R}_{2}=\mathrm{OMe}, \quad \mathrm{R}_{3}=\mathrm{Ac}, \quad \mathrm{R}_{4}=\mathrm{H}, \quad \mathrm{R}_{5}=\mathrm{H}, \quad \mathrm{R}_{6}=\mathrm{OMe}$

$14 \mathrm{R}_{1}=\mathrm{R}_{2}=\mathrm{OMe}, \quad \mathrm{R}_{3}=\mathrm{R}_{4}=\mathrm{Ac}, \quad \mathrm{R}_{5}=\mathrm{OMe}, \quad \mathrm{R}_{6}=\mathrm{OH}$

$17 \mathrm{R}_{1}=\mathrm{R}_{2}=\mathrm{OMe}, \quad \mathrm{R}_{3}=\mathrm{R}_{4}=\mathrm{Ac}, \quad \mathrm{R}_{5}=\mathrm{R}_{6}=\mathrm{OMe}$

$18 \mathrm{R}_{1}=\mathrm{R}_{2}=\mathrm{OMe}, \quad \mathrm{R}_{3}=\mathrm{R}_{4}=\mathrm{Ac}, \quad \mathrm{R}_{5}=\mathrm{H}, \quad \mathrm{R}_{6}=\mathrm{OMe}$

$21 \mathrm{R}_{1}-\mathrm{R}_{2}=-\mathrm{OCH}_{2} \mathrm{O}-, \quad \mathrm{R}_{3}=\mathrm{R}_{4}=\mathrm{Ac}, \quad \mathrm{R}_{5}=\mathrm{R}_{6}=\mathrm{OMe}$

$22 \mathrm{R}_{1}-\mathrm{R}_{2}=-\mathrm{OCH}_{2} \mathrm{O}-, \quad \mathrm{R}_{3}=\mathrm{R}_{4}=\mathrm{Ac}, \quad \mathrm{R}_{5}=\mathrm{H}, \quad \mathrm{R}_{6}=\mathrm{OMe}$<smiles>[R]c1cc2c([R3])c3c(c(-c4ccc5c(c4)OCO5)c2cc1[R])COC3=O</smiles>

20

$\mathrm{R}_{1}=\mathrm{R}_{2}=\mathrm{R}_{3}=\mathrm{OMe}$

23

Fig. 3 Structures of compounds 3-23 


\section{7}
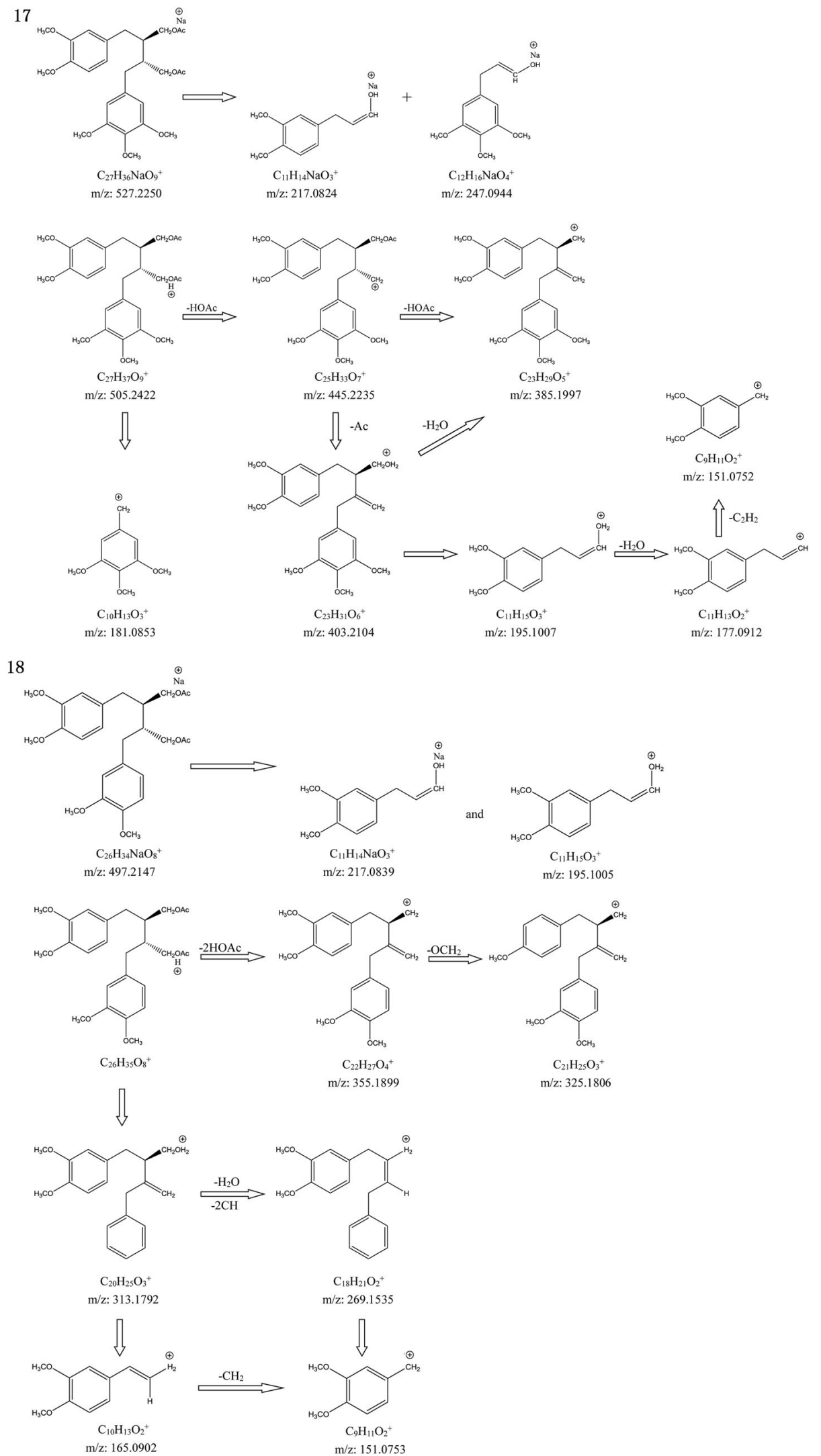

Fig. 4 Proposed fragmentation pattern of compounds 17 and 18 
<smiles>COc1cc(C/C=C/O)cc(OC)c1O[Mg]O[Na]</smiles>

fragment ions at $m / z 247.0931,195.1009,181.0851$, and 151.0759 were the same as those in compound 17 (Fig. 4). The structure was deduced as (-)-dihydroclusin diacetate [3].

Compound 22 showed a $[\mathrm{M}+\mathrm{Na}]^{+}$ion at $m / z 481.1809$, and its chemical formula is $\mathrm{C}_{25} \mathrm{H}_{30} \mathrm{O}_{8}$. The ion at $\mathrm{m} / z$ 339.1580 was attributed to the loss of diacetate from the parent ion. The characteristic fragment ions at $\mathrm{m} / \mathrm{z}$ 201.0527, 177.0904, 165.0910, 151.0753, and 135.0449 were also observed in compounds 17 and 19. The structure was identified as 2,3-demethoxysecisolintetralin acetate [9].

\section{Identification of arylnaphthalenes}

Arylnaphthalene lignans have the phenyl-naphthyl skeleton. The following steps are mandatory to obtain characteristic fragment: First, the cleavage of the glycosidic bonds to the aglycone take place to yield the $\mathrm{m} / \mathrm{z}$ of the arylnaphthalene lignan without the neutral mass of the released sugars; second, when all glycosidic bonds are broken, the fragmented with the aglycone $\mathrm{m} / \mathrm{z}$ is obtained; finally, characteristic fragmentations are showed the loss of $\mathrm{CO}_{2}, \mathrm{CH}_{2}$, and $\mathrm{H}_{2} \mathrm{O}$ groups from aglycone ion.

Compound 3 with the $[\mathrm{M}+\mathrm{Na}]^{+}$ion at $m / z 537.1351$ $\left(\mathrm{C}_{26} \mathrm{H}_{26} \mathrm{NaO}_{11}{ }^{+}\right)$showed the neutral loss of $162 \mathrm{Da}$ (glucosyl residue), producing a fragment ion at $\mathrm{m} / \mathrm{z} 353.1012$ $\left(\mathrm{C}_{20} \mathrm{H}_{17} \mathrm{O}_{6}^{+}\right)$. Compound 5 showed a $[\mathrm{M}+\mathrm{Na}]^{+}$ion at $m / z 567.1475\left(\mathrm{C}_{27} \mathrm{H}_{28} \mathrm{NaO}_{12}{ }^{+}\right)$that eliminated a glucosyl residue of $162 \mathrm{Da}$ to produce an ion at $\mathrm{m} / \mathrm{z} 383.1113$ $\left(\mathrm{C}_{21} \mathrm{H}_{19} \mathrm{O}_{7}^{+}\right)$. Compound 11 showed a $[\mathrm{M}+\mathrm{H}]^{+}$ion at $\mathrm{m} / z 513.1395\left(\mathrm{C}_{26} \mathrm{H}_{25} \mathrm{O}_{11}{ }^{+}\right)$and the aglycone fragment ion at $m / z 381.0951(-132 \mathrm{Da}$, an apioside residue). Compound 15 showed a $[\mathrm{M}+\mathrm{H}]^{+}$ion at $m / z 555.1495$ $\left(\mathrm{C}_{28} \mathrm{H}_{27} \mathrm{O}_{12}{ }^{+}\right)$and produced an important fragment ion at $m / z 513.1407$ (the loss of acetate moiety). The other characteristic fragments were the same as those in compound 11. Compound 23 produced a $[\mathrm{M}+\mathrm{H}]^{+}$ion at $m / z$ $349.0648\left(\mathrm{C}_{20} \mathrm{H}_{13} \mathrm{O}_{6}{ }^{+}\right)$. The fragmentations of compounds $3,5,11,15$, and 23 showed the loss of $\mathrm{CO}_{2}, \mathrm{CH}_{2}$, and $\mathrm{H}_{2} \mathrm{O}$ 
groups from parent ion or aglycone ion (Compound 5 as an example is shown in Fig. 6). None of the isomers of the five compounds were observed in the high-resolution mass spectrum and bibliography, unique arylnaphthalenes in J. procumbens. Compounds 3, 5, 11, 15, and 23 were identified as procumbenoside $\mathrm{L}$, procumbenoside $\mathrm{K}$, tuberculatin, diphyllin apioside-5-acetate, and Justicidin E by matching with the literatures [10-15].

Some other arylnaphthalenes in J. procumbens have the same molecular weight and the same fragment ion patterns, such as justicidinoside $C$ and cleistanthin $B$ [14, 15]. Further, the stereochemistry of compounds $4,8,9,10$, 16,19 , and 20 were determined by ${ }^{1} \mathrm{H}-\mathrm{NMR}$ and compared to the literature. Compound 4 showed a molecular ion $[\mathrm{M}+\mathrm{Na}]^{+}$peak at $m / z 565.1319\left(\mathrm{C}_{27} \mathrm{H}_{26} \mathrm{NaO}_{12}{ }^{+}\right)$ and produced a product ion at $\mathrm{m} / z 381.0953$ (the loss of glucosyl residue). Compound 8 showed a $[\mathrm{M}+\mathrm{Na}]^{+}$peak at $m / z 595.1420\left(\mathrm{C}_{28} \mathrm{H}_{28} \mathrm{NaO}_{13}{ }^{+}\right)$; a fragmentation at $\mathrm{m} / z$ $411.1063\left(\mathrm{C}_{22} \mathrm{H}_{19} \mathrm{O}_{8}{ }^{+}\right)$was attributed to the elimination of a glucosyl residue. Compound 9 showed a $[\mathrm{M}+\mathrm{H}]^{+}$ peak at $m / z 675.1892\left(\mathrm{C}_{32} \mathrm{H}_{35} \mathrm{O}_{16}{ }^{+}\right)$. The parent ion produced a peak at $m / z 513.1393\left(\mathrm{C}_{26} \mathrm{H}_{25} \mathrm{O}_{11}{ }^{+}\right)$via the loss of a glucosyl residue $(162 \mathrm{Da})$; further fragmentation of this ion showed a peak at $m / z 381.0951\left(\mathrm{C}_{21} \mathrm{H}_{17} \mathrm{O}_{7}{ }^{+}\right)$ due to the loss of an apiosyl residue (132 Da). Compound 10 produced a $[\mathrm{M}+\mathrm{H}]^{+}$peak at $\mathrm{m} / z 645.1806$ $\left(\mathrm{C}_{31} \mathrm{H}_{33} \mathrm{O}_{15}{ }^{+}\right)$; the fragment at $m / z 513.1393\left(\mathrm{C}_{26} \mathrm{H}_{25} \mathrm{O}_{11}{ }^{+}\right)$ can be attributed to the cleavage of a xylosyl residue (132 Da) and $381.0951\left(\mathrm{C}_{21} \mathrm{H}_{17} \mathrm{O}_{7}^{+}\right)$due to the removal of an apiosyl residue from $\mathrm{C}_{26} \mathrm{H}_{25} \mathrm{O}_{11}{ }^{+}$. Compound 16 showed a $[\mathrm{M}+\mathrm{Na}]^{+}$ion at $m / z 387.0824\left(\mathrm{C}_{21} \mathrm{H}_{16} \mathrm{NaO}_{6}{ }^{+}\right)$. Compound 19 showed a $[\mathrm{M}+\mathrm{H}]^{+}$ion at $\mathrm{m} / z 395.1108$ $\left(\mathrm{C}_{22} \mathrm{H}_{19} \mathrm{O}_{7}^{+}\right)$. Compound 20 showed a $[\mathrm{M}+\mathrm{H}]^{+}$ion at $m / z 395.1110\left(\mathrm{C}_{22} \mathrm{H}_{19} \mathrm{O}_{7}{ }^{+}\right)$, too. In the ${ }^{1} \mathrm{H}$-NMR spectra of $4,8,9,10,16,19$, and 20 typical signals due to the arylnaphthalene lignan, were observed along with the signals owing to the sugar portion (Tables 2 and 3). Compounds $4,8,9,10,16,19$ and 20 were tentatively identified as

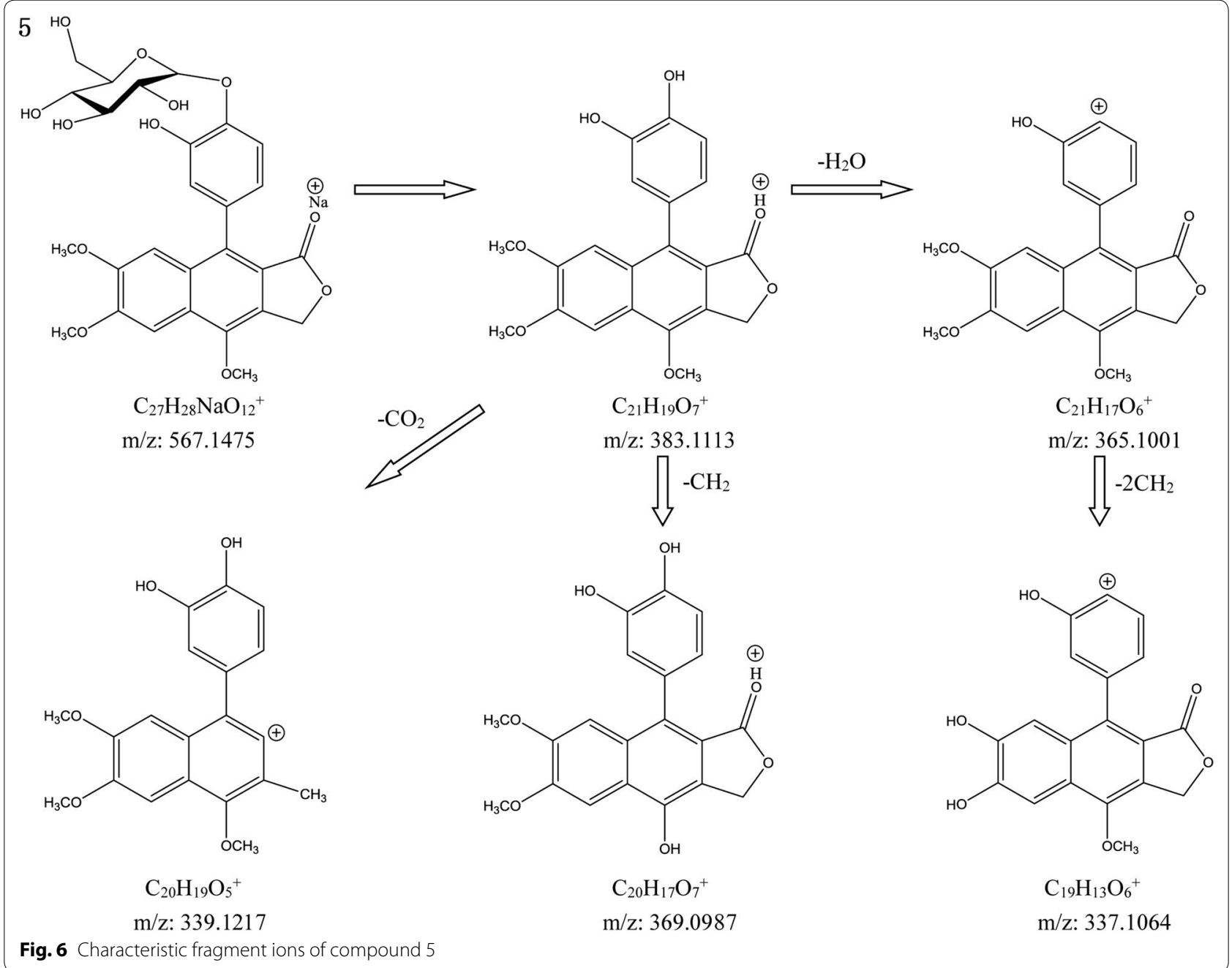


Table $2{ }^{1} \mathrm{H}$-NMR data for compounds 4, 8, 9, and $10\left(\mathrm{CD}_{3} \mathrm{OD}\right)$

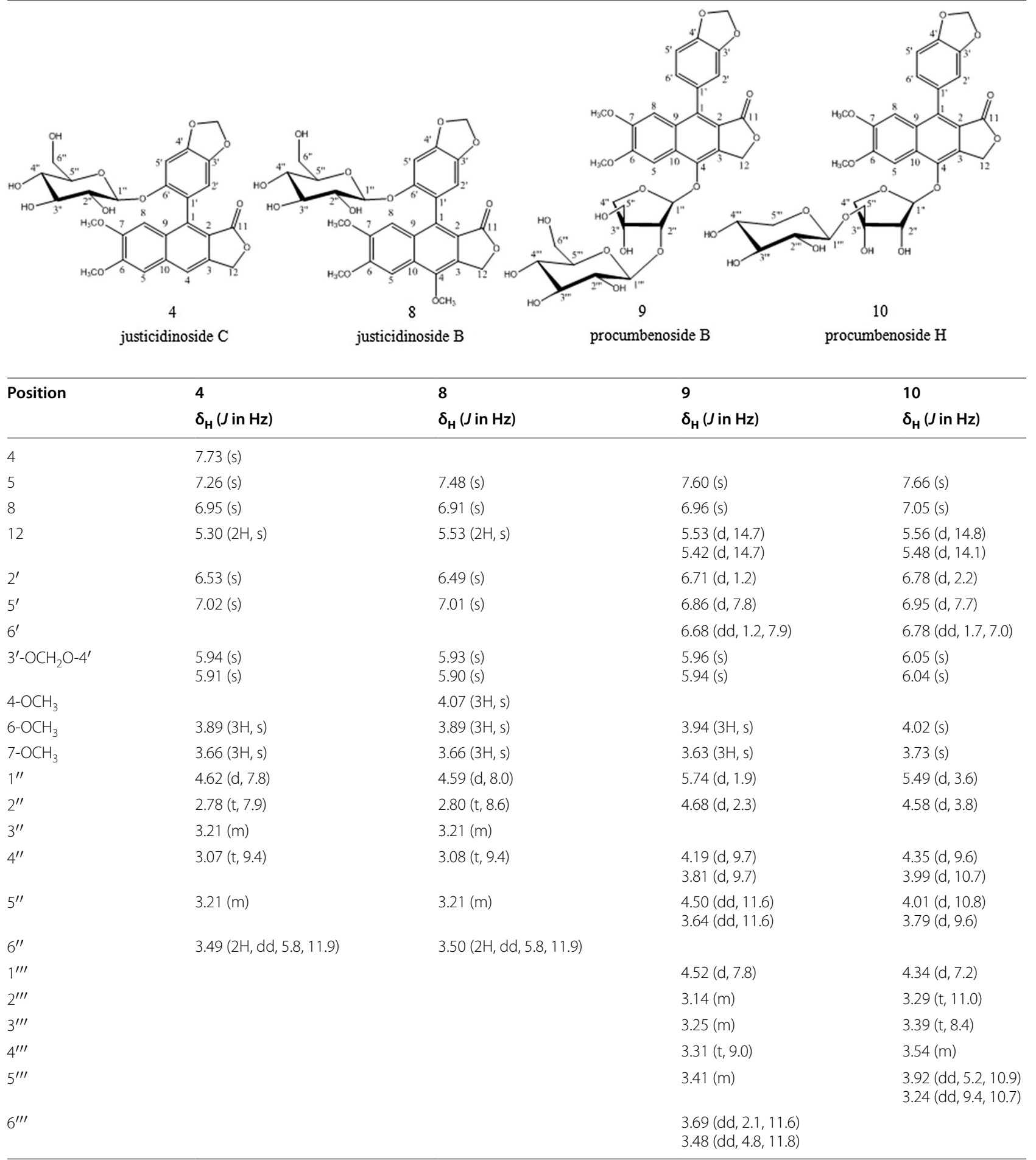




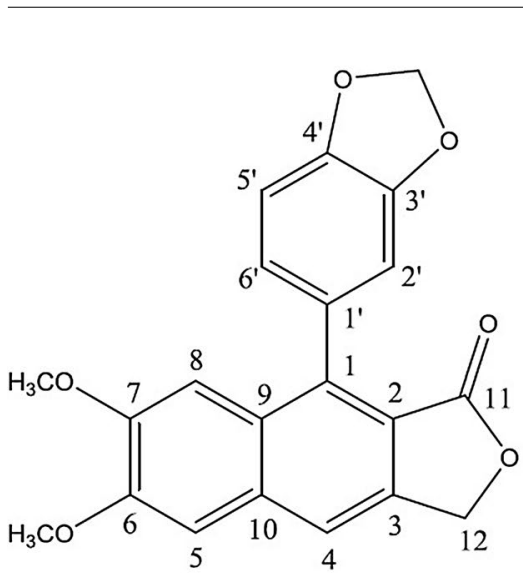

16<smiles>COc1ccc(-c2c3c(c(OC)c4cc5c(cc24)OCO5)C(=O)OC3)cc1OC</smiles>

19<smiles>COc1cc2c(OC)c3c(c(-c4ccc5c(c4)OCO5)c2cc1OC)COC3=O</smiles>

20

justicidin B chinensinaphthol methyl ether neojusticin $\mathrm{B}$

\begin{tabular}{|c|c|c|c|c|}
\hline \multirow[t]{2}{*}{ Position } & 16 & 20 & Position & 19 \\
\hline & $\delta_{H}(J$ in $\mathrm{Hz})$ & \multicolumn{2}{|l|}{$\delta_{\mathbf{H}}(J$ in $\mathrm{Hz})$} & $\delta_{H}(J$ in Hz) \\
\hline 4 & $7.72(\mathrm{~s})$ & & 4 & \\
\hline 5 & $7.23(\mathrm{~s})$ & 7.41 (s) & 5 & 7.35 (s) \\
\hline 8 & 7.01 (s) & $7.00(\mathrm{~s})$ & 8 & 6.99 (s) \\
\hline 11 & & $5.17(2 \mathrm{H}, \mathrm{s})$ & 11 & \\
\hline 12 & $5.39(2 \mathrm{H}, \mathrm{s})$ & & 12 & $5.41(2 \mathrm{H}, \mathrm{s})$ \\
\hline $2^{\prime}$ & $6.86(d, 1.5)$ & $6.85(d, 1.6)$ & $2^{\prime}$ & $6.91(s)$ \\
\hline $5^{\prime}$ & $6.94(d, 7.9)$ & $6.98(d, 8.0)$ & $5^{\prime}$ & $7.03(\mathrm{~s})$ \\
\hline $6^{\prime}$ & $6.80(\mathrm{dd}, 1.5,7.8)$ & $6.82(\mathrm{dd}, 1.6,8.1)$ & $6^{\prime}$ & $\begin{array}{l}6.76(\mathrm{dd}, 1.6 \\
8.0)\end{array}$ \\
\hline \multirow[t]{2}{*}{$3^{\prime}-\mathrm{OCH}_{2} \mathrm{O}-4^{\prime}$} & $5.98(s)$ & $6.06(s)$ & $3^{\prime}-\mathrm{OCH}_{3}$ & $3.86(3 \mathrm{H}, \mathrm{s})$ \\
\hline & $5.94(\mathrm{~s})$ & $6.00(s)$ & $4^{\prime}-\mathrm{OCH}_{3}$ & $3.70(3 \mathrm{H}, \mathrm{s})$ \\
\hline $4-\mathrm{OCH}_{3}$ & & $4.31(3 \mathrm{H}, \mathrm{s})$ & $4-\mathrm{OCH}_{3}$ & $4.03(3 \mathrm{H}, \mathrm{s})$ \\
\hline $6-\mathrm{OCH}_{3}$ & $3.85(3 \mathrm{H}, \mathrm{s})$ & $3.95(3 \mathrm{H}, \mathrm{s})$ & $6-\mathrm{OCH}_{2} \mathrm{O}-7$ & $6.17(2 \mathrm{H}, \mathrm{d})$ \\
\hline $7-\mathrm{OCH}_{3}$ & $3.64(3 \mathrm{H}, \mathrm{s})$ & $3.72(3 \mathrm{H}, \mathrm{s})$ & & \\
\hline
\end{tabular}

justicidinoside $C$, justicidinoside $B$, procumbenoside $B$, procumbenoside $H$, justicidin $B$, chinensinaphthol methyl ether, and neojusticin $\mathrm{B}$, respectively, by comparing with the literatures $[3,16-18]$.

\section{Structural analysis of novel compound 12}

Compound 12 chemical formula is $\mathrm{C}_{25} \mathrm{H}_{34} \mathrm{O}_{8}$, which was deduced from the positive-ion HR-ESI-MS $(\mathrm{m} / z$ 485.2140 $\left.[\mathrm{M}+\mathrm{Na}]^{+}\right)$. The ${ }^{1} \mathrm{H}-\mathrm{NMR}$ and ${ }^{13} \mathrm{C}-\mathrm{NMR}$ spectra (Table 4 and Fig. 7) showed signals of acetate hydrogens at $\delta 2.07\left(3 \mathrm{H}, \mathrm{s}, \mathrm{H}-11^{\prime}\right)$ and carbons at $\delta$ $21.11\left(1 \mathrm{C}, \mathrm{C}-11^{\prime}\right), 171.05\left(1 \mathrm{C}, \mathrm{C}-10^{\prime}\right)$. This acetate was located at the position ${\mathrm{C}-9^{\prime}}^{\prime}$ based on the HMBC spectrum correlation between $\mathrm{H}-9^{\prime}$ and $\mathrm{C}-10^{\prime}$. The ${ }^{1} \mathrm{H}-$ NMR spectrum also showed signal of five aromatic hydrogens at $\delta 6.29(1 \mathrm{H}, \mathrm{d}, \mathrm{H}-2$ or 6$), 6.30(1 \mathrm{H}, \mathrm{d}, \mathrm{H}-2$ or 6) of ring $\mathrm{B}$ and an $\mathrm{ABX}$ system of ring $\mathrm{A}$ at $\delta 6.63$ $\left(1 \mathrm{H}, \mathrm{m}, \mathrm{H}-2^{\prime}\right), 6.76\left(1 \mathrm{H}, \mathrm{m}, \mathrm{H}-5^{\prime}\right), 6.66\left(1 \mathrm{H}, \mathrm{m}, \mathrm{H}-6^{\prime}\right)$. 
Table $4{ }^{13} \mathrm{C}(200 \mathrm{MHz})$ and ${ }^{1} \mathrm{H}-\mathrm{NMR}(800 \mathrm{MHz})$ data for compound $12\left(\mathrm{CDCl}_{3}\right)$

\begin{tabular}{llllll}
\hline Position & $\boldsymbol{\delta}_{\mathbf{C}}$ & $\boldsymbol{\delta}_{\mathbf{H}}(\boldsymbol{J} \mathbf{i n ~ H z})$ & Position & $\boldsymbol{\delta}_{\mathbf{C}}$ & $\boldsymbol{\delta}_{\mathbf{H}}(\boldsymbol{J} \mathbf{~ i n ~ H z})$ \\
\hline 1 & 136.11 & & $1^{\prime}$ & 132.40 & \\
2 & 105.70 & 6.29 or $6.30(\mathrm{~d}, 1.7)$ & $2^{\prime}$ & 111.90 & $6.63(\mathrm{~m})$ \\
3 & 153.10 & & $3^{\prime}$ & 147.33 & \\
4 & 153.10 & $4^{\prime}$ & 148.84 & \\
5 & 153.10 & & $5^{\prime}$ & 111.04 & $6.76(\mathrm{~m})$ \\
6 & 105.70 & 6.29 or $6.30(\mathrm{~d}, 1.7)$ & $6^{\prime}$ & 120.91 & $6.66(\mathrm{~m})$ \\
$7 \mathrm{a}$ & 35.83 & $2.61(\mathrm{~m})$ & $7^{\prime} \mathrm{a}$ & 34.99 & $2.65(\mathrm{~m})$ \\
$7 \mathrm{~b}$ & & $2.75(\mathrm{~m})$ & $7^{\prime} \mathrm{b}$ & & $2.70(\mathrm{~m})$ \\
8 & 42.97 & $1.95(\mathrm{~m})$ & $8^{\prime}$ & 39.59 & $2.21(\mathrm{~m})$ \\
9 & 62.59 & $3.67(2 \mathrm{H}, \mathrm{dtt})$ & $9^{\prime} \mathrm{a}$ & 64.69 & $4.06(\mathrm{ddd})$ \\
& & & $9^{\prime} \mathrm{b}$ & & $4.24(\mathrm{ddd})$ \\
$3-\mathrm{OCH}_{3}$ & 60.89 & $3.80(3 \mathrm{H}, \mathrm{s})$ & $1^{\prime}$ & 171.05 & \\
$4-\mathrm{OCH}_{3}$ & 60.89 & $3.80(3 \mathrm{H}, \mathrm{s})$ & $1^{\prime}$ & 21.11 & $2.07(3 \mathrm{H}, \mathrm{s})$ \\
$5-\mathrm{OCH}_{3}$ & 60.89 & $3.80(3 \mathrm{H}, \mathrm{s})$ & $3^{\prime}-\mathrm{OCH}_{3}$ & 55.83 & $3.86(3 \mathrm{H}, \mathrm{s})$ \\
& & & $4^{\prime}-\mathrm{OCH}_{3}$ & 56.03 & $3.83(3 \mathrm{H}, \mathrm{s})$ \\
\hline
\end{tabular}

Atom numbering as indicated in Fig. 7

All assignments are based on ${ }^{1} \mathrm{H}-{ }^{1} \mathrm{H}$ COSY, $\mathrm{HSQC}$, and $\mathrm{HMBC}$ data

The corresponding carbons and methoxyls signals of benzene rings could be confirmed by the HSQC and HMBC spectra. According to the ${ }^{1} \mathrm{H}_{-}{ }^{1} \mathrm{H}$ COSY spectrum of butyl portion, $\delta 4.06\left(1 \mathrm{H}\right.$, ddd, $\left.\mathrm{H}-9^{\prime} \mathrm{a}\right)$ and $\delta$ $4.24\left(1 \mathrm{H}, \mathrm{ddd}, \mathrm{H}-9^{\prime} \mathrm{b}\right)$ showed correlation with the hydrogen signal at $\delta 2.21\left(1 \mathrm{H}, \mathrm{m}, \mathrm{H}-8^{\prime}\right), \delta 2.21(1 \mathrm{H}, \mathrm{m}$, $\left.\mathrm{H}-8^{\prime}\right)$ showed correlation with the hydrogen signal at $\delta$ $2.65\left(1 \mathrm{H}, \mathrm{m}, \mathrm{H}-7^{\prime} \mathrm{a}\right)$ and $\delta 2.70\left(1 \mathrm{H}, \mathrm{m}, \mathrm{H}-7^{\prime} \mathrm{b}\right), \delta 3.67$ $(2 \mathrm{H}, \mathrm{dtt}, \mathrm{H}-9 \mathrm{a}, 9 \mathrm{~b})$ showed correlation with the hydrogen signal at $\delta 1.95(1 \mathrm{H}, \mathrm{m}, \mathrm{H}-8), \delta 1.95(1 \mathrm{H}, \mathrm{m}, \mathrm{H}-8)$ showed correlation with the hydrogen signal at $\delta 2.61$ $(1 \mathrm{H}, \mathrm{m}, \mathrm{H}-7 \mathrm{a})$ and $\delta 2.75(1 \mathrm{H}, \mathrm{m}, \mathrm{H}-7 \mathrm{~b})$. The corresponding carbons signals of butyl could be confirmed by HSQC spectrum. The above mentioned spectroscopic data suggested that novel compound 12 is 2-(3,4-dimethoxybenzyl)-4-hydroxy-3-(3,4,5-trimethoxybenzyl)butyl acetate, which we named 5-methoxy4,4'-di-O-methylsecolariciresinol-9' ${ }^{\prime}$-monoacetate [3].

\section{Quantification of the six standard lignans}

The maximum absorption peak of the arylnaphthalene lignans were around $260 \mathrm{~nm}$. Therefore, the wavelength for the content determination of justicidinoside $B$, justicidinoside $\mathrm{C}$, procumbenoside $\mathrm{H}$, justicidin $\mathrm{B}$, chinensinaphthol methyl ether, and neojusticin $B$ were set at $260 \mathrm{~nm}$. The content of procumbenoside B was not determined, because it was not separated with other compounds. The chromatograms of sample and mixed standard were shown in Fig. 8.
Standard curves were constructed by plotting the peak area against the corresponding concentration of the standard solutions. The limits of detection (LOD) and quantification (LOQ) were determined by diluting the working solutions when the signal-to-noise ratios $(\mathrm{S} / \mathrm{N})$ of about 3 and 10, respectively. The detailed descriptions of the curves were presented in Table 5.

The intra-day and inter-day assay precisions were respectively carried out on the mixture standard solution of six analytes six times a day and once a day for six sequential days, respectively. For the stability testing, the same sample was analyzed every $8 \mathrm{~h}$ within $48 \mathrm{~h}$ at the room temperature. The method repeatability was examined by the injection of six different sample, which were prepared with the same sample preparation procedure. The mean content of method repeatability were the content of six lignans in the ethyl acetate extract. Recovery was determined by adding an accurately known amount of the corresponding marker compounds to the known sample. The recovery rate and RSD for analytes at different concentrations were determined. All results were shown in Table 6.

The quality standard of $J$. procumbens has been included in the 1977 version of the Chinese Pharmacopoeia. However, this standard lacked the qualitative and quantitative analytical methods. This result will provide a scientific basis for the quality control of $J$. procumbens.

\section{Conclusions}

Using a combination of liquid chromatography, highresolution MS and NMR techniques, 23 compounds were identified, and four novel compounds $(1,2,12$, and 13) are reported for the first time. A HPLC-DAD-MS method was developed for the first time to analyze the chemical constituents of $J$. procumbens and detected the content of six lignans. The above results indicated that these compounds were the active chemical components responsible for the cytotoxic properties of $J$. procumbens.

Among 23 lignans, justicidin $\mathrm{B}$, tuberculatin, and procumbenoside $\mathrm{H}$ have been proven potent cytotoxic activity against the Human LoVo and BGC-823 cell lines [18]. Chinensinaphthol methyl ether exhibited cytotoxic activity against the human leukemia K562 cell line [19]. Dihydroclusin diacetate had cytotoxic activity against the M12.C3.F3 and RAW264.7 murine cell lines [20]. Diphyllin apioside-5-acetate and neojusticin B showed cytotoxic against the cultured rabbit lung cell [14]. These reports also supported the cytotoxic activity of the ethyl acetate extract of J. procumbens.

This study identified the lignan constituents in the ethyl acetate extract of J. procumbens. The whole landscape of 


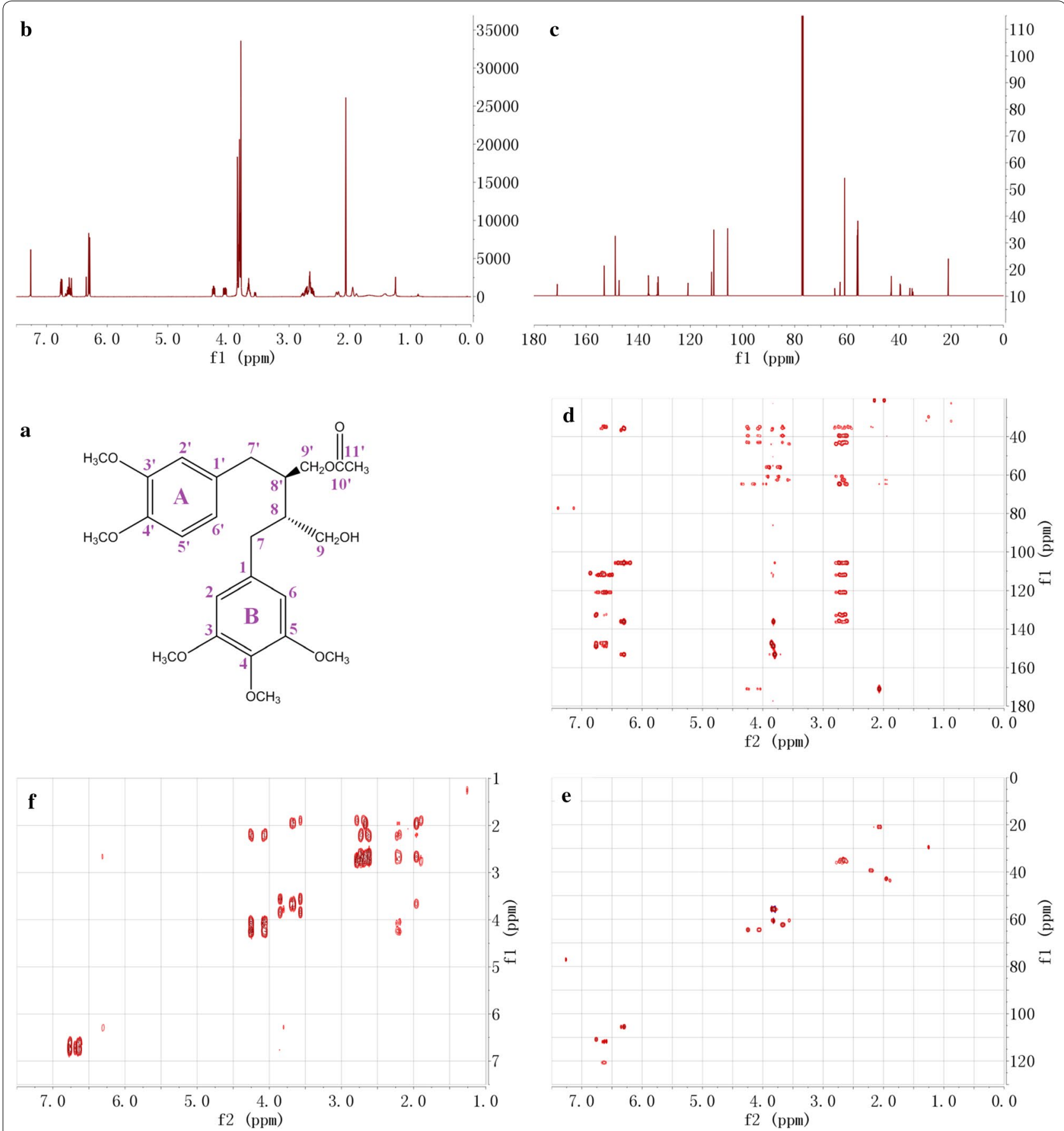

Fig. 7 NMR spectra of compound 12: a chemical structure, $\mathbf{b}^{1} \mathrm{H}-\mathrm{NMR}$ spectrum, $\mathbf{c}^{13} \mathrm{C}-\mathrm{NMR}$ spectrum, $\mathbf{d} \mathrm{HMBC}$ spectrum, e $\mathrm{HSQC}$ spectrum, ${ }^{1} \mathrm{H}-$ ${ }^{1} \mathrm{H}$ COSY spectrum

characteristic chromatogram data of lignans has been established. The complete and systematic phytochemistry studies are underway. After isolation of more pure constituents, the activities of individual compounds will be determined in the future, and the structure-activity relationship will be established. 


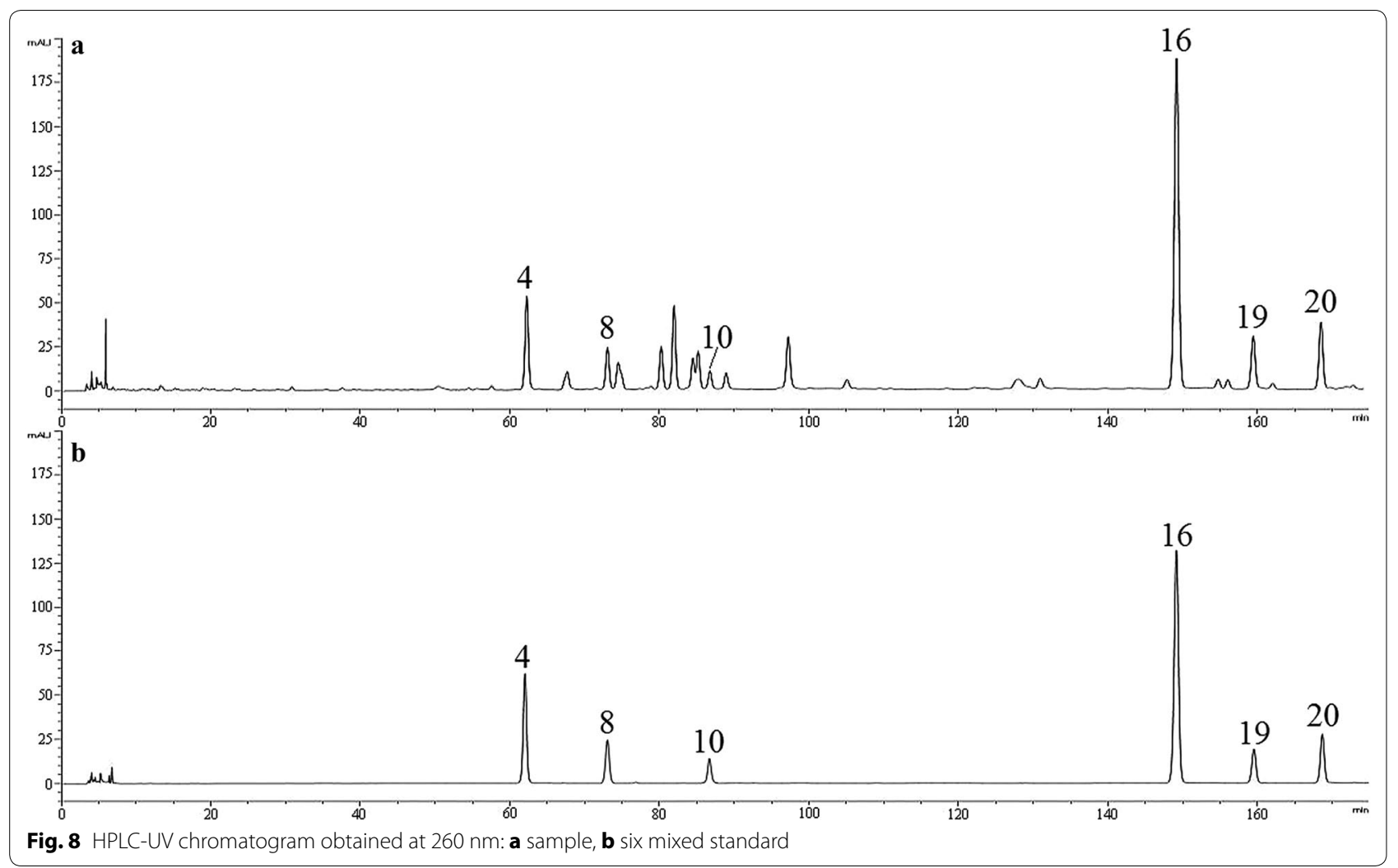

Table 5 Linear regression data, LOD, and LOQ of six standard lignans

\begin{tabular}{llllll}
\hline Standard & Regression equation & Linear range $(\boldsymbol{\mu g} / \mathbf{m l})$ & $\mathbf{r}^{\mathbf{2}}$ & LOD $(\boldsymbol{\mu g} / \mathbf{m l})$ & $\mathbf{L O Q}(\boldsymbol{\mu g} / \mathbf{m l})$ \\
\hline 4 & $Y=34.3060 x-2.2863$ & $3.7-118$ & 0.9999 & 0.021 & 0.071 \\
8 & $y=57.9005 x-3.3266$ & $2.6-84$ & 0.9999 & 0.013 & 0.044 \\
10 & $y=13.8900 x-5.3980$ & $2.3-74$ & 0.9998 & 0.043 & 0.142 \\
16 & $y=119.9074 x-40.5723$ & $5.8-184$ & 0.9999 & 0.005 & 0.017 \\
19 & $y=44.7432 x-18.4394$ & $2.1-68$ & 0.9998 & 0.017 & 0.057 \\
20 & $y=19.3973 x-23.6537$ & $6.9-220$ & 0.9998 & 0.034 & 0.113 \\
\hline
\end{tabular}

In the regression equation $Y=a X+b, X$ refers to the concentrations $(\mu \mathrm{g} / \mathrm{ml}), Y$ is the peak area

Table 6 Precision, repeatability, stability, recovery, and content of six standard lignans

\begin{tabular}{|c|c|c|c|c|c|c|c|}
\hline \multirow[t]{2}{*}{ Standard } & \multicolumn{2}{|c|}{ Precision (RSD \%) } & \multirow[t]{2}{*}{ Repeatability (RSD \%) } & \multirow[t]{2}{*}{ Stability (RSD \%) } & \multicolumn{2}{|c|}{ Recovery } & \multirow[t]{2}{*}{ Content $^{\mathrm{a}}(\mathrm{mg} / \mathrm{g})$} \\
\hline & Intra-day & Inter-day & & & Mean & RSD \% & \\
\hline 4 & 0.86 & 1.63 & 1.78 & 1.39 & 101.49 & 1.66 & 34.70 \\
\hline 8 & 0.99 & 1.37 & 1.93 & 0.88 & 101.20 & 1.97 & 8.93 \\
\hline 10 & 1.10 & 1.85 & 1.96 & 1.16 & 98.63 & 2.00 & 10.10 \\
\hline 16 & 0.64 & 0.99 & 1.31 & 0.73 & 100.51 & 1.53 & 28.36 \\
\hline 19 & 0.92 & 1.72 & 1.81 & 1.57 & 99.37 & 1.95 & 12.22 \\
\hline 20 & 0.51 & 0.94 & 1.35 & 0.94 & 99.04 & 1.83 & 29.05 \\
\hline
\end{tabular}

a Content of six lignans in the ethyl acetate extract 
This newly developed HPLC-DAD-ESI-MS method also provides a pathway to study the accumulation and distribution of secondary metabolites in J. procumbens and serves as a good strategy for the quality control of this plant.

\section{Authors' contributions}

HZW conceived the research idea. BL and YFY conducted the experiments. $\mathrm{HBL}, \mathrm{ZTX}, \mathrm{QL}, \mathrm{DM}, \mathrm{FPL}$, and JLP were assistants in experimental work. BL and YFY compiled all the data and prepared the manuscript. All authors read and approved the final manuscript.

\section{Author details}

${ }^{1}$ Faculty of Pharmacy, Hubei University of Chinese Medicine, No.1, Huangjiahu West Road, Wuhan 430065, China. ${ }^{2}$ Key Laboratory of Traditional Chinese Medicine Resources and Chemistry of Hubei Province, Wuhan 430065, People's Republic of China. ${ }^{3}$ Collaborative Innovation Center of Traditional Chinese Medicine of New Products for Geriatrics Hubei Province, Wuhan 430065, China. ${ }^{4}$ Wuhan Institute of Physics and Mathematics (WIPM) of Chinese Academy of Sciences, West No.30 Xiao Hong Shan, Wuhan 430071, China.

\section{Acknowledgements}

This work was supported by the National Natural Science Foundation of China (Grant No. 31570343).

Yanfang Yang-Co-first author.

\section{Competing interests}

The authors declare that they have no competing interests.

\section{Ethics approval and consent to participate}

Not applicable.

\section{Publisher's Note}

Springer Nature remains neutral with regard to jurisdictional claims in published maps and institutional affiliations.

Received: 5 January 2017 Accepted: 8 January 2018

Published online: 25 January 2018

\section{References}

1. Awan AJ, Ahmed CB, Uzair M, Aslam MS, Farooq U, Ishfaq K (2014) Family Acanthaceae and genus Aphelandra: ethnopharmacological and phytochemical review. Int J Pharm Pharm Sci 10:44-55

2. Luo Z, Kong W, Qiu F, Yang M, Li Q, Wei R, Yang X, Qin J (2013) Simultaneous determination of seven lignans in Justicia procumbens by high performance liquid chromatography-photodiode array detection using relative response factors. J Sep Sci 36:699-705

3. Chen CC, Hsin WC, Huang YL (1998) Six new diarylbutane lignans from Justicia procumbens. J Nat Prod 61:227-229

4. Yang M, Wu J, Cheng F, Zhou Y (2006) Complete assignments of $1 \mathrm{H}$ and 13C NMR data for seven arylnaphthalide lignans from Justicia procumbens. Magn Reson Chem 44:727-730
5. Wei JF, Gao PR, Wang JM, Kang WY (2016) Analysis of tilianin and acacetin in Agastache rugosa by high-performance liquid chromatography with ionic liquids-ultrasound based extraction. Chem Cent J 10:1-9

6. Sharma N, Bhardwaj V, Singh S, Ali SA, Gupta DK, Paul S, Satti NK, Chandra S, Verma MK (2016) Simultaneous quantification of triterpenoic acids by high performance liquid chromatography method in the extracts of gum resin of Boswellia serrata obtained by different extraction techniques. Chem Cent J 10:2-10

7. Kato MJ, Yoshida M, Gottlieb OR (1990) Lignoids and acylresorcinols from Virolaelongata. Phytochemistry 29:1799-1810

8. Fonseca SF, Nielsen LT, Ruveda EA (1979) Lignans of Araucaria angustifolia and ${ }^{13} \mathrm{C}$ NMR analysis of some phenyltetralin lignans. Phytochemistry 18:1703-1708

9. Satyanarayana P, Venkateswarlu S (1991) Isolation, structure and synthesis of new diarylbutane lignans from Phyllanthus niruri: synthesis of $5^{\prime}$-desmethoxy niranthin and an antitumour extractive. Tetrahedron 47:8931-8940

10. Jin $\mathrm{H}$ (2014) Chemical constituents and biological activities of Justicia procumbens. Doctoral Dissertation, Beijing Institute of Radiation Medicine of the Academy of Military Medical Sciences, Beijing

11. Amborabé BE, Fleurat-Lessard P, Roblin G (2002) Antifungal effects of salicylic acid and other benzoic acid derivatives towards Eutypa lata: structure-activity relationship. Plant Physiol Biochem 40:1051-1060

12. Wu CM, Wu SC, Lin CN (2007) Antiplatelet effect and selective binding to cyclooxygenase (COX) by molecular docking analysis of flavonoids and lignans. Int J Mol Sci 8:830-841

13. Mabberley DJ (1997) The Plant-book: a portable dictionary of the vascular plants. Cambridge University Press, Cambridge

14. Asano J, Chiba K, Tada M, Yoshii T (1996) Antiviral activity of lignans and their glycosides from Justicia procumbens. Phytochemistry 42:713-717

15. Day S, Chiu N, Lin C (1999) Cytotoxic lignans of Justicia ciliata. J Nat Prod 62:1056-1058

16. Liu GR, Wu J, Si JY, Wang J, Yang M (2008) Complete assignments of ${ }^{1} \mathrm{H}$ and ${ }^{13} \mathrm{C}$ NMR data for three new arylnaphthalene lignan from Justicia procumbens. Magn Reson Chem 46:283-286

17. Weng JR, Ko HH, Yeh TL, Lin HC, Lin CN (2004) Two new arylnaphthalide lignans and antiplatelet constituents from Justicia procumbens. Arch Pharm 35:207-212

18. Jin H, Chen L, Tian Y, Li B, Dong JX (2015) New cyclopeptide alkaloid and lignan glycoside from Justicia procumbens. J Asian Nat Prod Res 17:33-39

19. Luo JY, Hu YC, Kong WJ, Yang M (2014) Evaluation and structure-activity relationship analysis of a new series of Arylnaphthalene lignans as potential anti-tumor agents. PLoS ONE 9:e93516

20. Messina F, Curini M, Di SC, Zadra C, Gigliarelli G, Rascon-Valenzuela LA Robles ZRE, Marcotullio MC (2015) Diterpenoids and triterpenoids from the resin of Bursera microphylla and their cytotoxic activity. J Nat Prod 78:1184-1188

\section{Submit your manuscript to a SpringerOpen ${ }^{\odot}$ journal and benefit from:}

- Convenient online submission

- Rigorous peer review

- Open access: articles freely available online

- High visibility within the field

- Retaining the copyright to your article

Submit your next manuscript at $\boldsymbol{\nabla}$ springeropen.com 